УДК $598.2(26)(571.65)$

\title{
ЧАСТОТА ВСТРЕЧАЕМОСТИ КЛУБНЫХ ПАР БОЛЬШОЙ КОНЮГИ (AETHIA CRISTATELLA) ПРИ ВЫСОКОЙ И РЕЗКО СНИЗИВШЕЙСЯ ЧИСЛЕННОСТИ ПТИЦ В КОЛОНИИ
}

\author{
Зубакин В. А. ${ }^{1}$, Зубакина Е. В. ${ }^{2}$, Клёнова А. В. ${ }^{3}$, Водолазова Д. С. ${ }^{3}$ \\ ${ }^{I}$ ФББУН Институт проблем экологии и эволючии имени А. Н. Севериова, г. Москва \\ E-mail: vzubakin@yandex.ru \\ ${ }^{2}$ Общероссийская общественная организаџия Союз охраны птии России, г. Москва \\ E-mail: rbcu@yandex.ru \\ ${ }^{3}$ Биологический факультет Московского государственного университета им. М. В. Ломоносова, \\ 2. Москва \\ E-mail: anna.v.klenova@gmail.com
}

\begin{abstract}
Большая конюга - некрупная планктоноядная морская птица семейства чистиковых (Alcidae), обладающая сложным социальным поведением, одна из интересных форм которого - формирование клубных пар помимо существующих брачных. Изучение частоты встречаемости клубных пар проводили на о. Талан (Охотское море) в 1988-1989 гг., когда колония находилась в благополучном состоянии, и в 2008-2015 гг., когда ее численность уменьшилась (к 2008 г. - в 3 раза). Исследования показали, что доля особей, имеющих клубные пары, более высока в период высокой численности колонии (35\%) и ниже в колонии, снижающей численность (18 \%), различия не достоверны. В оба периода исследований от 73 \% (1988-1989 гг.) до 80 \% (2008-2015 гг.) особей были постоянны в следовании выбранной стратегии формирования или не формирования клубных пар, как минимум, в течение двух сезонов размножения подряд. Прослеживается связь между наличием клубных пар и распадом брачных пар в следующий сезон размножения, но клубные партнеры становятся затем брачными партнерами, по-видимому, относительно редко.
\end{abstract}

Ключевые слова: морские птицы, чистиковые, успех размножения, брачные демонстрации, поведение, большая конюга, Охотское море.

Большая конюга - некрупная планктоноядная морская птица семейства чистиковых (Alcidae) отряда Ржанкообразных (Charadriiformes), гнездящаяся большими колониями в каменных осыпях на береговых склонах островов и мысов морей северной части Тихого океана (Конюхов, 1990). Большие конюги - моногамы, родители вносят примерно равный вклад в заботу о потомстве. Свое единственное яйцо птицы откладывают в щелях и нишах между камней осыпи, реже - в норах на задернованных участках осыпи (Gaston, Jones, 1998). В периоды формирования пар и насиживания конюги в дневное время находятся в море, за исключением насиживающих особей. В колонии птицы появляются в вечернее и утреннее время и проводят там несколько часов; в период выкармливания птенцов этот ритм сбивается, и птицы прилетают в колонию в том

(C) Зубакин В. А., Зубакина Е. В., Клёнова А. В., Водолазова Д. С., 2021 числе и в дневные часы (Byrd et al., 1983). Для больших конюг характерно сложное социальное поведение, которое можно наблюдать на поверхности осыпей в вечерний и особенно утренний период их активности (Харитонов, 1980, 2007; Зубакин, 1990, 2007; Jones, 1993). Птицы формируют так называемые клубы - скопления холостых и свободных от насиживания особей, в которых конюги отдыхают, исполняют демонстрации саморекламирования, конфликтуют с соседями и проявляют элементы брачного поведения. Все эти формы поведения можно наблюдать в клубах в течение почти всего периода размножения, вплоть до начала интенсивного выкармливания птенцов (Бахтурина, Клёнова, 2015).

Одна из интереснейших форм социального поведения большой конюги - формирование клубных пар. То есть птица, уже имеющая брачного партнера, может образовать дополнительную пару (или даже несколько пар) в клубе с особями противоположного пола (Зубакин, 1990, 2007). 
Завершается ли формирование такой клубной пары спариванием, осталось не выясненным, поскольку копуляция у конюг происходит в море (Зубакин и др., 2010). Известно, однако, что частота внебрачных спариваний у большой конюги очень невелика и не превышает 10 \% (Hunter, Jones, 1999). Формирование клубной пары можно проследить по появлению специфической брачной демонстрации - биллингу, или дуэту, во время которого две птицы противоположного пола располагаются друг напротив друга, сблизив клювы часто до соприкосновения, распушив оперение шеи и слегка «пощипывая» друг у друга клюв и оперение головы и горла. Биллинг больших конюг обычно сопровождается вокализациями обоих партнеров, так называемым клохтанием, и является неотъемлемой частью процесса формирования и поддержания брачных пар у этого вида (Jones, 1993; Seneviratne et al., 2009; Зубакин и др., 2010). Эту демонстрацию можно наблюдать в клубах на поверхности осыпей в течение всего сезона размножения - от периода формирования брачных пар до начала интенсивного выкармливания птенцов, причем примерно с одинаковой частотой (Бахтурина, Клёнова, 2015). Биллинг отмечается в разных ситуациях (при встрече партнеров, в ответ на приближение конспецифика к паре, в ответ на биллинг соседней пары и т. п.), но чаще всего птицы исполняют его без внешних воздействий, при взаимодействии с партнером (Бахтурина, 2014).

Изучение социального поведения большой конюги было начато в 1987-1991 гг. на о. Талан и продолжено там же в 2008-2015 гг. За 20 лет, прошедших между этими циклами исследований, в поселении морских птиц на о. Талан произошли серьезные изменения. В конце 1980-х - начале 1990-х гг. на этом острове площадью всего около 2.5 км$^{2}$ гнездилось более 1.3 млн морских птиц 12 видов (Кондратьев и др., 1992). Такое обилие объяснялось сочетанием топографических и гидрологических условий, способствующих формированию стационарных круговых течений и холодных фронтов, что обеспечивало изобилие планктона на доступном для конюг расстоянии от острова (Андреев и др., 2010). Однако с тех пор численность ряда морских птиц, большой конюги особенно, здесь катастрофически снизилась. Если в начале 1990-х гг. большая конюга была самым многочисленным видом, насчитывающим более 1 млн особей, то к 2007-2008 гг. ее численность сократилась до 260-300 тыс. особей, а к 2017 г. уменьшилась до 35-37 тыс. особей (Кондратьев и др., 1992; Андреев и др., 2010; Андреев, Голубова, 2019). Если в 1987-2006 гг. доля покинувших гнездовую камеру птенцов от числа отложенных яиц составляла в среднем $52.8 \%$, то в 2007-2017 гг. она снизилась до
16.7 \%. Нулевой успех размножения впервые был зафиксирован в 2007 г., впоследствии он повторился в 2010-2011 и 2014-2017 гг. Непосредственной причиной этих драматических изменений стало снижение доступности корма - макропланктона (эуфаузид) в период инкубации и выкармливания птенцов, вызванное воздействием климатических факторов (Андреев, Голубова, 2019).

Таким образом, первый цикл наших исследований проходил в колонии, находившейся в благоприятных кормовых условиях и при высокой численности гнездящихся конюг, тогда как второй цикл попал на резкое снижение численности птиц в колонии из-за многолетней бескормицы. В результате мы получили уникальную возможность проследить влияние резко ухудшившихся условий внешней среды на демографические и поведенческие характеристики большой конюги и сравнить социальное поведение этого вида в благополучной и деградирующей колониях. В своей предшествующей работе (Водолазова и др., 2021) мы касались различий между циклами исследований в выживаемости взрослых птиц, в частоте распадения брачных пар и смены гнездовых камер. Целью настоящей работы было выяснить, как повлияло резкое снижение численности колонии на частоту встречаемости клубных пар.

\section{МЕТОДЫ}

Материал был собран на о. Талан (59² $18^{\prime}$ с. ш., $149^{\circ} 04^{\prime}$ в. д.), расположенном в Тауйской губе Охотского моря примерно в 100 км от г. Магадан, в 1988-1989 и в 2008-2015 гг. (кроме 2012 г., когда остров не посещали). Наблюдения за клубными партнерами проводили в период с начала июня, когда у большинства конюг уже появились кладки, до середины июля, когда птицы были заняты выкармливанием птенцов и социальная активность на поверхности осыпей практически прекращалась. Отлов, мечение и наблюдения за индивидуально опознаваемыми птицами в оба цикла исследований осуществляли на одном и том же экспериментальном участке, расположенном на склоне западной экспозиции на высоте 5-15 м н. у. м., площадь которого

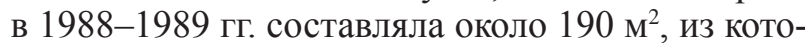
рых примерно $44 \mathrm{~m}^{2}$ приходилось на обнаженную каменную осыпь, а остальное - на задернованную осыпь с отдельными валунами и гнездовыми камерами конюг. Во второй цикл исследований конюги перестали посещать большую часть прежде занимаемой ими задернованной осыпи в нижней части экспериментального участка, и находящаяся под наблюдением площадь фактически сократилась до $82 \mathrm{~m}^{2}$. На экспериментальном участке в 1988-1989 гг. размножались 75-90 пар 
больших конюг, а в 2008-2010 гг. - около 50 пар. В период с 2010 по 2015 г. для мечения и наблюдения использовали также добавочный экспе-

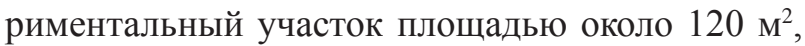
расположенный на склоне северной экспозиции на высоте около 25 м н. у. м. В годы наблюдений здесь гнездились около 80 пар больших конюг. На обоих участках на поверхности камней они формировали клубы, где в утреннее время отдыхали и проявляли социальную активность.

Наряду с данными о падении численности больших конюг, полученными другими исследователями (Андреев и др., 2010; Андреев, Голубова, 2019), мы использовали в качестве показателя изменения численности результаты подсчета количества больших конюг, находившихся в период утренней активности на поверхности осыпи. Учеты птиц проводились 1 раз в час на одной и той же части западного склона острова, в период с 22 июня по 4 июля (вторая половина периода насиживания) в 1988-1989 и в 2008-2010 гг. Для дальнейшего анализа использовались максимальные значения численности конюг, полученные за утро.

Для мечения конюг отлавливали 1 раз в 24 дня с помощью небольших сеточек с петлями из лески, которые размещали на поверхности «посадочных» и клубных камней, и рыболовных сетей, которыми закрывали входы в гнездовые камеры; в первый цикл исследований использовали также поставленные вертикально сети, в которые попадали конюги, слетающие со склона в море. Каждую пойманную птицу снабжали металлическим кольцом с уникальным номером и индивидуальным набором цветных пластиковых колец. У особей, отловленных в 2008-2015 гг., брали по 5-7 контурных перьев для определения пола методом ПЦР-амплификации ДНК (Griffiths et al., 1998; Cerit, Avanus, 2007). Если пол птицы не был установлен методом ПЦР-амплификации ДНК, его определяли на основе морфологических параметров (главным образом по высоте клюва) и по поведению особей (Jones, 1993; Зубакин и др., 2010). Всего в 1988-1989 гг. было окольцовано 100, а в 2008-2015 гг. - 339 взрослых половозрелых больших конюг.

Наблюдения за мечеными птицами проводили по возможности ежедневно из стационарных засидок, расположенных в нескольких метрах от границ экспериментальных участков. Наблюдения обычно осуществляли примерно с 5:00-7:00 до 11:00-13:00, по ходу сезона размножения их начало постепенно смещали на более позднее время в связи со сдвигом времени активности конюг. Кроме фиксации присутствия на участке меченых особей, по заходам птиц в их гнездовые камеры и выходам из них отмечали месторасположение таких камер, регистрировали наличие или отсутствие у птиц корма для птенца, а также отмечали партнеров меченых особей во время исполнения брачных демонстраций.

Партнерами мы считали особей, исполняющих описанный выше биллинг и/или регулярно заходящих в одну и ту же гнездовую камеру. Если особь на протяжении сезона размножения исполняла биллинг с единственным партнером, его считали брачным партнером. Если партнеров по брачной демонстрации было два и более, то брачным партнером считался тот, с кем особь исполняла брачные демонстрации биллинга наиболее часто и/или с которым регулярно заходила в одну и ту же гнездовую камеру. Остальных партнеров, с которыми особь исполняла биллинг реже или однократно, считали клубными партнерами (Водолазова и др., 2021).

Для оценки частоты встречаемости клубных партнеров мы использовали только пары, где оба брачных партнера были индивидуально опознаваемы. При этом если у особи были известны брачные партнеры в течение двух и более лет, мы учитывали эту особь для каждого года независимо. В первом цикле исследований данные о партнерах были собраны от 29 особей (из них для 18 особей мы имели сведения о брачном и клубных партнерах только за 1 сезон, для 11 - за 2 сезона; всего, таким образом, для анализа мы имели 40 фактов наличия у особи брачного партнера при наличии или отсутствии клубного партнера). Во втором цикле данные получены от 57 особей (для 39 особей - за 1 сезон, а для 18 особей за 2-5 последовательных сезонов, что дало для дальнейшего анализа 89 фактов наличия у особи брачного партнера при наличии или отсутствии клубного партнера). Частоту встречаемости клубных партнеров определяли как процент особей, имевших двух и более партнеров (включая брачного), от общего количества вошедших в анализ особей (от 40 для первого и 89 для второго цикла исследований). Кроме конюг, у которых и брачные, и клубные партнеры были индивидуально помечены, мы использовали в расчетах также меченых птиц, у которых, кроме окольцованного брачного партнера, присутствовал также немеченый клубный партнер. В таком случае мы не могли точно сказать, сколько клубных партнеров было у такой птицы, но отмечали факт наличия как минимум одного клубного партнера помимо точно известного брачного. Показатель встречаемости клубных партнеров подсчитывали как для всех птиц суммарно, так и отдельно для самцов и самок. Статистическую обработку данных проводили в программе Statistica 8.0 (StatSoft, Inc.) с использованием четырехпольного теста $\chi^{2}$ с поправкой Йетса (Yates corrected Chi-square). 


\section{РЕЗУЛЬТАТЫ}

В 1988-1989 гг. в находящейся в поле зрения наблюдателя части западного склона острова в утренний период активности максимально находилось от 109 до 194 особей (в среднем, по данным за 11 дней, 143 особи), в 2008 г. на той же площади - от 60 до 90 особей (в среднем, по данным за 7 дней, 75 особей), в 2009 г. - от 25 до 81 особи (в среднем, по данным за 7 дней, 50 особей), в 2010 г. - только от 0 до 29 особей (в среднем, по данным за 5 дней, 17 особей). К 2015 г. социальная активность конюг практически сошла на нет: прилетев в колонию, птицы, как правило, почти сразу же «ныряли» в осыпь к своим гнездовым камерам, а не оставались, как в предшествующие годы, на камнях для участия в разнообразных социальных взаимодействиях.

В 1988-1989 гг. клубные партнеры были отмечены у 14 (35\%) из 40 больших конюг, чей брачный партнер был точно известен: у 8 из 20 самцов $(40 \%)$ и у 6 из 20 самок (30\%). Из 14 особей, имевших клубных партнеров, у 3 птиц (1 самец и 2 самки) было по 2 клубных партнера помимо точно установленного брачного партнера, у остальных 11 особей (7 самцов и 4 самки) - по 1 клубному партнеру.

В 2008-2015 гг. клубные партнеры были отмечены у 16 (18\%) из 89 больших конюг, чей брачный партнер был точно известен: у 5 из 43 самцов (12\%) и 11 из 46 самок (22\%). Из 16 особей, имевших клубных партнеров, у 1 самца отмечены 2 таких партнера, у остальных 4 самцов и 11 самок - по одному.

Таким образом, процент особей, имеющих клубных партнеров, в 2008-2015 гг. был вдвое меньше, чем в 1988-1989 гг; различия, однако, были не достоверны, хотя и близки к первому порогу достоверности $\left(\chi^{2}=3.58, p=0.058\right)$. При этом у самцов в 1988-1989 гг. клубные партнеры встречались достоверно чаще, чем в 20082015 гг. $\left(\chi^{2}=5.09, p=0.024\right)$, тогда как у самок частота встречаемости клубных партнеров не различалась между периодами исследования $\left(\chi^{2}=0.05, p=0.831\right)$. Различия в частоте встречаемости клубных партнеров у самцов и самок для обоих циклов исследования оказались недостоверными $\left(\chi^{2}=0.11, p=0.740\right.$ для 1988-1989 гг. и $\chi^{2}=1.52, p=0.218$ для 2008-2015 гг.).

Из 11 больших конюг, брачные партнеры которых были точно известны как в 1988 г., так и в 1989 г., 2 особи (самцы) имели клубных партнеров в оба этих года, 3 особи (1 самец и 2 самки) имели клубных партнеров в один из этих годов, остальные 6 особей (3 самца и 3 самки) не имели клубных партнеров ни в 1988 г., ни в 1989 г. Из 15 больших конюг, брачные партнеры которых были точно известны как минимум два последовательных сезона в 2008-2015 гг., 2 особи (самки) име- ли клубных партнеров в каждый из этих сезонов (3 и 2 сезона подряд соответственно), 10 особей (7 самцов и 3 самки) не имели клубных партнеров ни в один из этих сезонов, остальные 3 особи (1 самец и 2 самки) имели клубных партнеров в одном из сезонов, но не имели в последующих. Таким образом, 8 из 11 особей (73\%) в 1988 1989 гг. и 12 из 15 особей (80\%) в 2008-2015 гг. по крайней мере в течение двух сезонов показали определенное постоянство в наличии или отсутствии клубных партнеров.

Из находившихся под наблюдением в 1988 1989 гг. 14 пар, в которых все брачные партнеры на следующий год возвратились в колонию, в следующем сезоне распались 8 пар, сохранилось 6 пар. Из 8 распавшихся пар в 5 (63\%) хотя бы у одного брачного партнера в предыдущем сезоне был клубный партнер, из 6 сохранившихся пар брачные партнеры в предыдущем сезоне были только у одной пары $(17 \%)$. Другими словами, 5 из 6 брачных пар (83\%), у которых в предшествующий год были отмечены клубные партнеры, распались в следующем году, тогда как у пар, не имевших клубных партнеров, распались только 3 из 8 (38\%) брачных пар. Выборка слишком мала, чтобы с полной уверенностью утверждать о связи между наличием клубных пар и последующим распадом брачных пар, но такая тенденция, безусловно, прослеживается.

\section{ОБСУЖДЕНИЕ}

Двукратное снижение доли особей, имеющих клубных партнеров в период 2008-2015 гг. по сравнению с периодом 1988-1989 гг., выглядит логичным в связи с резким падением численности больших конюг в колонии на о. Талан. Как уже отмечалось, с конца 1980-х - начала 1990-х гг. по 2007-2008 гг. численность этого вида здесь уменьшилась втрое (Андреев и др., 2010), а к 2016-2017 гг. по сравнению с 2007-2008 гг. - еще примерно в 10 раз (Андреев, Голубова, 2019). Общее снижение численности привело, по нашим данным, к уменьшению количества конюг, находящихся на поверхности осыпей в период утренней активности в колонии: в 2008 г. по сравнению с 1988-1989 гг. почти в 2 раза, в 2009 г. - почти в 3 раза, в 2010 г. - более, чем в 8 раз. Снижение численности на поверхности осыпей не могло не приводить к уменьшению количества контактов с другими особями, что, по-видимому, сказалось на частоте формирования клубных пар.

Вместе с тем различие в доле особей, имеющих клубных партнеров, в годы высокой численности и после катастрофического ее снижения оказалось хотя и заметным, но статистически не достоверным. Это может свидетельствовать, с одной стороны, о существующей тенденции к уменьшению процента особей с клубными пара- 
ми при снижении численности птиц в колонии, а с другой - об определенной степени устойчивости данной черты биологии больших конюг, меняющейся в гораздо меньшей степени, чем можно было ожидать при таких масштабах снижения численности.

Клубные пары у больших конюг отмечены не только на о. Талан, но и в других частях ареала этого вида - на Алеутских островах, о-вах Диомида и о. Св. Лаврентия (Jones, 1993; наши данные). В последние годы наличие клубных пар наблюдается и у ряда других чистиковых птиц - таких, как белобрюшка (Cyclorrhynchus psittacula), ипатка (Fratercula corniculata) и топорок (Lunda cirrhata) (Водолазова и др., 2021), однако даже в период депрессии численности 2008-2015 гг. доля особей, имеющих клубных партнеров, у большой конюги была выше, чем у перечисленных видов, не испытавших такого резкого падения численности (Водолазова и др., 2021). Повидимому, достаточно частую встречаемость клубных пар (по нашим данным, от одной пятой до одной трети особей в колонии имеет клубных партнеров) можно рассматривать в качестве одного из видовых признаков большой конюги.

Отдельный вопрос представляет функциональное значение клубных пар. Существует точка зрения, что их формирование у больших конюг способствует выбору другого, возможно, более качественного брачного партнера на следующий сезон (Jones, 1993). Подтверждением этого, как представляется, выступает тот факт, что, помимо нередко встречающихся клубных пар, для больших конюг характерен также высокий процент распадения брачных пар при живых обоих партерах (Zubakin, Zubakina, 1993) - так называемых разводов (divorce, по: Jones, 1993). По нашим данным, связь между наличием клубных пар и «разводами» прослеживается - брачные пары, у членов которых были клубные партнеры, в следующем сезоне распадались чаще, чем пары, клубных партнеров не имевшие (в 83 и $38 \%$ случаев соответственно). Однако прежние клубные партнеры становятся на следующий сезон брачными партнерами, видимо, лишь изредка. В 1988-1989 гг. отмечены два случая, когда клубные партнеры на следующий год стали брачной парой, и один случай, когда брачная пара сформировалась из клубных партнеров через год, пропустив один сезон. В большинстве же случаев новые пары возникают не из прежних клубных партнеров или же установить наличие или отсутствие идентичности клубных и брачных партнеров не удается.

Судя по всему, причина появления клубных пар у больших конюг может лежать не столько в необходимости выбора более качественного партнера, сколько в более общих закономерностях сексуального поведения, его связи с психологическим типом и иными индивидуальными особенностями особи; в этом отношении феномен клубных пар у больших конюг, возможно, сходен с таким явлением, как флирт в человеческом обществе (Зубакин, 2007). Разнокачественность брачного поведения больших конюг проявляется как в разной степени постоянства брачных пар у разных особей, так и в склонности к формированию клубных пар, причем, как показано выше, от 73 до 80 \% особей придерживались избранной стратегии формирования или не формирования клубных пар на протяжении, как минимум, двух сезонов. Индивидуальные особенности проявляются и в других формах поведения большой конюги, например, в приуроченности основной демонстрации саморекламирования (триумфального крика) к определенным ситуациям. Так, было показано, что в клубах отдельные самцы предпочитают издавать триумфальные крики в присутствии конспецификов, но при отсутствии партнеpa, в то время как другие - при отсутствии конспецификов и партнера, а третьи - при наличии конспецификов и партнера (Комарова, Клёнова, 2018). Яркие индивидуальные особенности ранее также были описаны как во внешнем виде (С. П. Харитонов, личное сообщение), так и в акустических характеристиках триумфальных криков большой конюги (Клёнова и др., 2011; Klenova et al., 2012).

Необходимо подчеркнуть, что формирование пар, как брачных, так и клубных, у конюг представляет собой не хаотичный процесс, наподобие броуновского движения, как это нередко воспринимается при поверхностном наблюдении. Некоторые факты трудно объяснить иначе, как наличием определенной доли симпатии между особями. Так, в 1988 г. помеченный зелеными кольцами самец после длительных столкновений «отбил» самку у соседнего самца. В 1989 г. эта самка вернулась к своему прежнему самцу, а в 1990 г., после исчезновения (видимо, гибели) последнего вновь сформировала брачную пару с самцом с зелеными кольцами.

Таким образом, наличие клубных партнеров в колонии у заметной доли особей, по-видимому, можно считать одним из видовых признаков большой конюги; эта доля более высока при стабильной высокой численности колонии и имеет тенденцию к уменьшению в колонии, снижающей численность. Как в благополучный период существования колонии, так и в период коллапса поселения подавляющее большинство особей в течение как минимум двух сезонов были постоянны в выборе одной из двух стратегий: либо формировать, либо не формировать клубные пары. Прослеживается связь между наличием клубных пар и распадением брачных пар в 
следующий сезон размножения, однако клубные партнеры становятся затем брачными партнерами, судя по всему, достаточно редко.

Исследование выполнено при финансовой поддержке гранта Президента РФ (МК-1781. 2012.4) и РФФИ (12-04-00414a).

\section{БЛАГОДАРНОСТИ}

Авторы выражают глубокую благодарность всем сотрудникам лаборатории орнитологии Института биологических проблем Севера ДВО РАН за предоставленную возможность проведения полевых исследований на о. Талан. Особую благодарность авторы выражают А. В. Андрееву, Е. Ю. Голубовой, А. С. Китайскому, А. Я. Кондратьеву, Л. Ф. Кондратьевой, Ю. А. Слепцову и С. П. Харитонову за помощь в проведении экспедиций и сборе данных, а И. А. Володину и Н. Б. Конюхову - за ценные советы при подготовке рукописи в печать.

\section{ЛИТЕРАТУРА}

Андреев А. В., Голубова Е. Ю. Многолетняя динамика численности и успеха размножения большой конюги Aethia cristatella Pallas, 1769 на острове Талан (Охотское море) // Вестник ТвГУ. Сер. Биология и экология. 2019. Т. 1, № 53. С. 15-30.

Андреев А. В., Голубова Е. В., Зубакин В. А., Харитонов $C$. П. Численность морских птиц на колониях о. Талан: двадцатилетний тренд // Вестник СевероВосточного научного центра ДВО РАН. 2010. № 2. C. $30-42$.

Бахтурина Д. С. Сравнительная характеристика дуэтных демонстраций чистиковых птиц на примере трех видов (большая конюга Aethia cristatella, белобрюшка Cyclorrhynchus psittacula, ипатка Fratercula corniculata). Москва : МГУ, 2014. 117 с.

Бахтурина Д. С., Клёнова А. В. Сравнительный анализ поведения трех видов чистиковых птиц (Charadriiformes, Alcidae) (большой конюги (Aethia cristatella), белобрюшки (Cyclorrhynchus psittacula) и ипатки (Fratercula corniculata) на поверхности колонии // Зоологический журнал. 2015. Т. 94, № 9. C. 1084-1100.

Водолазова Д. С., Клёнова А. В., Зубакин В. А., Зубакина $E . B$. Демографические и этологические характеристики закрытогнездящихся чистиковых птиц колонии острова Талан (Охотское море): изменения за 20 лет // Зоологический журнал. 2021. Т. 100, № 11. C. $1262-1275$.

Зубакин В. А. Некоторые аспекты гнездовой биологии и социального поведения большой конюги (Aethia cristatella) // Изучение морских колониальных птиц в СССР. Магадан : ИБПС ДВО РАН, 1990. C. 9-13.

Зубакин В. А. О социальной организации морских птиц // Методы и теоретические аспекты исследования морских птиц : Материалы V Всерос. школы по морской биологии. Ростов-на-Дону : Южный науч. центр РАН, 2007. С. 180-202.

Зубакин В. А., Володин И. А., Клёнова А. В., Зубакина Е. В., Володина Е. В., Лапиина Е. Н. Поведение большой конюги (Aethia cristatella) в период размножения: двигательные и акустические демонстрации // Зоологический журнал. 2010. Т. 89, № 3. С. 331-345.

Клёнова А. В., Зубакин В. А., Зубакина Е. В. Проявление индивидуальных особенностей в триумфальных криках высокосоциальной большой конюги (Aethia cristatella) // Вестник Московского университета. Сер. 16. Биология. 2011. № 3. С. 38-45.

Комарова В. А., Клёнова А. В. Влияние социального окружения на акустические параметры и встречаемость триумфального крика большой конюги (Aethia cristatella, Charadriiformes, Alcidae) // Зоологический журнал. 2018. Т. 97, № 7. С. 840-853.

Кондратьев А. Я., Зубакин В. А., Голубова Е. Ю., Кондратьева Л. Ф., Харитонов С. П., Китайский $A$. C. Фауна наземных позвоночных животных острова Талан // Прибрежные экосистемы северного Охотоморья. Остров Талан. Магадан : СВНЦ ДВО РАН, 1992. C. 72-108.

Конюхов Н. Б. Большая конюга // Птицы СССР. Чистиковые. Москва : Наука, 1990. С. 112-121.

Харитонов С. П. Материалы по птицам острова Ионы // Орнитология. 1980. Т. 15. С. 10-15.

Харитонов С. П. Изучение структуры колоний околоводных птиц // Методы и теоретические аспекты исследования морских птиц : Материалы V Bceрос. школы по морской биологии. Ростов-на-Дону : Южный науч. центр РАН, 2007. С. 122-147.

Byrd G. V., Day R. H., Knudtson E. P. Patterns of colony attendance and censusing of auklets of Buldir Island // Condor. 1983. 85 (3). P. 274-280.

Cerit H., Avanus K. Sex identification in avian species using DNA typing methods // World's Poultry Science Journal. 2007. 63 (1). P. 91-100.

Gaston A. J., Jones I. L. The auks. Oxford : Oxford University Press, 1998. P. 1-349.

Griffiths R., Double M. C., Orr K., Dawson R. J. A DNA test to sex most birds // Molecular Ecology. 1998. No. 7 (8). P. 1071-1075.

Hunter F. M., Jones I. L. The frequency and function of aquatic courtship and copulation in Least, Crested, Whiskered and Parakeet Auklets // Condor. 1999. No. 101. P. 518-528.

Jones I. L. Crested auklet (Aethia cristatella) // The Birds of North America. Washington, D.C., Philadelphia : The Academy of Natural Sciences. The American Ornithologists' Union, 1993. No. 70. P. 1-16.

Klenova A. V., Zubakin V. A., Zubakina E. V. Inter- and intra-season stability of vocal individual signatures in a social seabird, the crested auklet // Acta Ethologica. 2012. No. 15. P. 141-152.

Seneviratne S. S., Jones I. L., Miller E. H. Vocal repertoires of auklets (Alcidae: Aethini): structural organization and categorization // Wilson Journal of Ornithology. 2009. Vol. 121. P. 568-584.

Zubakin V. A., Zubakina E. V. Observations of colorbanded Alcidae at Talan Island, Okhotsk Sea // Beringian Seabird Bulletin. 1993. No. 1. P. 43-44. 


\title{
THE OCCURRENCE OF CLUB PAIRS OF THE CRESTED AUKLET (AETHIA CRISTATELLA) IN A PROSPEROUS AND A DEGRADING COLONY
}

\author{
V. A. Zubakin ${ }^{1}$, E. V. Zubakina ${ }^{2}$, A. V. Klenova ${ }^{3}$, D. S. Vodolazova ${ }^{3}$ \\ ${ }^{1}$ A. N. Severtsov Institute of Ecology and Evolution, Moscow \\ ${ }^{2}$ Russian Bird Conservation Union, Moscow \\ ${ }^{3}$ Biological Department of Lomonosov Moscow State University, Moscow
}

\begin{abstract}
The crested auklet is a medium-sized planktivorous seabird of the Alcidae family with complex social behavior, one of the interesting forms of which is the formation of club pairs in addition to existing breeding pairs. The occurrence of club pairs in this species was studied on the Talan Island (Sea of Okhotsk) in 1988-1989, when the colony was in a good condition, and in 2008-2015, when its population decreased several times. The research showed that the proportion of individuals with club partners is higher in a high-population period (35\%) and lower in a low-population period (18\%); the differences, however, are not significant. In both study periods, from $73 \%$ (1988-1989) to $80 \%(2008-2015)$ individuals were consistent in following the chosen strategy of forming or not forming club pairs for at least two seasons. The presence of club pairs seems to facilitate the change of mate in the next breeding season, but club mates then become partners relatively seldom.
\end{abstract}

Keywords: seabirds, Auks, breeding success, courtship displays, behavior, crested auklet, Sea of Okhotsk.

\section{REFERENCES}

Andreev, A. V., Golubova, Ye. Yu., 2019. Long-Term Dynamics of the Crested Auklet Aethia cristatella Pallas, 1769 Population and Its Breeding Success on Talan Island, Sea of Okhotsk, Vestnik TvGU Biology and Ecology. 1 (53), 15-30 [In Russian].

Andreev, A. V., Golubova, Y. Yu., Zubakin, V. A., Kharitinov, S. P., 2010. Abundance of Sea Birds on Talan Island: 20-Year Trend, Vestnik NESC FEB RAS. 2, 30-42 [In Russian].

Bakhturina, D. S., 2014. Comparative Description of Duet Displays of Three Auk Species (Crested Auklet Aethia cristatella, Parakeet Auklet Cyclorrhynchus psittacula, and Horned Puffin Fratercula corniculata). Moscow, Lomonosov Moscow State University [In Russian].

Bakhturina, D. S., Klenova, A. V., 2015. Quantitative Analysis of Behavior of Three Auk Species (Charadriiformes, Alcidae): Crested Auklet (Aethia cristatella), Parakeet Auklet (Cyclorrhynchus psittacula), and Horned Puffin (Fratercula corniculata), Zoologicheskii Zhurnal. 94 (9), 1084-1100 [In Russian].

Byrd, G. V., Day, R. H., Knudtson, E. P., 1983. Patterns of Colony Attendance and Censusing of Auklets of Buldir Island, Condor. 85 (3), 274-280.

Cerit, H., Avanus, K., 2007. Sex Identification in Avian Species Using DNA Typing Methods, World's Poultry Science Journal. 63 (1), 91-100.

Gaston, A. J., Jones, I. L., 1998. The Auks. Oxford, Oxford University Press. 1-349.

Griffiths, R., Double, M. C., Orr, K., Dawson, R. J., 1998. A DNA Test to Sex Most Birds, Molecular Ecology. 7 (8), 1071-1075.

Hunter, F. M., Jones, I. L., 1999. The Frequency and Function of Aquatic Courtship and Copulation in Least,
Crested, Whiskered and Parakeet Auklets, Condor. 101, 518-528.

Jones, I. L., 1993. Crested Auklet (Aethia cristatella), The Birds of North America. Washington, D.C., Philadelphia, The Academy of Natural Sciences, The American Ornithologists' Union. 70, 1-16.

Kharitonov, S. P., 1980. Materials on Iona Island Birds of, Ornithologia. 15, 10-15 [In Russian].

Kharitonov, S. P., 2007. The Study of the Semiaquatic Bird Colony Structure, Methods and Theoretical Aspects of the Seabird Study, Proceedings of the Fifth All-Russia School in Sea Biology. Rostov-on-Don, Southern Scientific Center of RAS. 122-147 [In Russian].

Klenova, A. V., Zubakin, V. A., Zubakina, E. V., 2012. Inter- and Intra-Season Stability of Vocal Individual Signatures in the Social Seabird, the Crested Auklet, Acta Ethologica. 15, 141-152.

Klenova, A. V., Zubakin, V. A., Zubakina, E. V., 2011. Individuality in Trumpet Calls of the Highly Social Crested Auklet (Aethia cristatella), Moscow University Bulletin. Series 16. Biology. 3, 38-45 [In Russian].

Komarova, V. A., Klenova, A. V., 2018. Social Environment Impact on the Acoustic Variables and Occurrence of the Crested Auklet Aethia cristatella, Charadriiformes, Alcidae, Zoologicheskii Zhurnal. 97 (7), 840-853 [In Russian].

Kondratyev, A. Ya., Zubakin, V. A., Golubova, E. Yu., Kondratyeva, L. F., Kharitonov, S. P., Kitaysky, A. S., 1992. Land Vertebrate Fauna of Talan Island, Coastal Ecosystems in the Northern Part of the Sea of Okhotsk. Talan Island. Magadan, NESC FEB RAS. 72-108 [In Russian].

Konyukhov, N. B., 1990. Crested Auklet, Birds of the USSR. The Auks. Moscow, Nauka. 112-121 [In Russian]. 
Seneviratne, S. S., Jones, I. L., Miller, E. H., 2009. Vocal Repertoires of Auklets (Alcidae: Aethini): Structural Organization and Categorization, Wilson Journal of Ornithology. 121, 568-584.

Vodolazova, D. S., Klenova, A. V., Zubakin, V. A., Zubakina, E. V., 2021. Demographic and Ethological Characteristics of Crevice-Nesting Auks at the Talan Island Colony, Sea of Okhotsk. Changes over 20 Years, Zoologicheskii Zhurnal. 100 (11), 1262-1275 [In Russian].

Zubakin, V. A., 1990. Some Aspects of the Nesting Biology and Social Behavior of the Crested Auklet Aethia cristatella, Colonial Seabirds Study in the USSR. Magadan, IBPN FEB RAS. 9-13 [In Russian].
Zubakin, V. A., 2007. On the Seabirds Social Organization, Methods and Theoretical Aspects of the Seabirds Study, Proceedings of the $5^{\text {th }}$ All-Russia School in Sea Biology. Rostov-on-Don, Southern Scientific Center of RAS. 180-202 [In Russian].

Zubakin, V. A., Volodin, I. A., Klenova, A. V., Zubakina, E. V., Volodina, E. V., Lapshina, E. K., 2010. Behaviour of the Crested Auklet (Aethia cristatella) in the Breeding Season: Visual and Acoustic Displays, Zoologicheskii Zhurnal. 89 (3), 331-345 [In Russian].

Zubakin V. A., Zubakina E. V., 1993. Observations of Color-Banded Alcidae at Talan Island, Okhotsk Sea, Beringian Seabird Bulletin. 1, 43-44. 